\title{
$\mathrm{Al}_{2} \mathrm{O}_{3} / \mathrm{Fe}$ 焼結複合材の溶融 $\mathrm{Pb}$ フリーハンダに対する 熱衝撃・濡れ特性の評価
}

\author{
川崎＼cjkstart潤１４徳田太郎*2 林 健太*3 木戸光夫
}

広島工業大学工学部機械システム工学科

J. Japan Inst. Metals, Vol. 74, No. 3 (2010), pp. 184-190

(C) 2010 The Japan Institute of Metals

\section{Evaluation of Thermal Shock Characteristic and Wettability of Melt Pb-Free Solder about $\mathrm{Al}_{2} \mathrm{O}_{3} / \mathrm{Fe}$ Composites}

Jun Kawasaki*1, Taro Tokuda*2, Kenta Hayashi*3 and Mitsuo Kido

Department of Mechanical Systems Engineering, Faculty of Technology, Hiroshima Institute of Technology, Hiroshima 731-5193

High solder wettability and thermal shock resistance are necessary for materials used for soldering tips. The thermal shock resistance of metal/ceramic composites was investigated, and each influencing factor is discussed in this study. The composites that have enough thermal shock resistance to be used as soldering tips are discussed. In addition, the factors that influenced the wettability of the composite material were investigated in order to improve the reliability of the solder wettability. The thermal shock characteristic of a Fe-added composite was clearly superior to a Ni-added composite. Both 20 mass $\%$ and 80 mass $\% \mathrm{Fe}^{-}$ added composites had greater wettability than $\mathrm{Ni}$-added composites, and this led to a decrease in the thermal shock temperature difference $\Delta T_{\mathrm{C}}$ and bending strength $\sigma_{\mathrm{BT}}$ following thermal shock. The solder wettability of metal/ceramic tips are dependant upon the surface temperature and heating time of the specimen. This decreased susceptibility to thermal shock was thought to be due to differences in the surface oxidation behavior caused by the tip heating condition. It is necessary to strictly limit those conditions in order to reliably evaluate wettability.

(Received September 24, 2009; Accepted November 30, 2009)

Keywords: lead-free solder, soldering iron, wettability, thermal shock, metal/ceramics composite

\section{1. 緒言}

近年環境問題の観点から, はんだの $\mathrm{Pb}($ 鉛)フリー化が進 められている.しかし, $\mathrm{Pb}$ フリーはんだは $\mathrm{Pb}$ 入りに比べ て溶融点が高いため，それに接触するはんだごて先端(チッ プ)表面部がはんだにより“食われる”，すなわち “チップ部 の溶食が進行”し，チップ構成材の寿命が極端に短くなって しまうなど，の問題をかかえている.

一方，はんだ付け作業をする上でチップ自身に求められる 特性としては, 上記の溶食性と, はんだに対する濡れ性さら に高い熱伝導率などがある.しかも，はんだごてチップは， 使用中常に加熱冷却という熱繰り返しをうけるため, 熱衝 撃(または熱サイクル) ${ }^{1,2}$ に対しても十分耐えうるものでな ければならない。

著者らはこれまで, $\mathrm{Al}_{2} \mathrm{O}_{3}$ セラミックスに $\mathrm{Fe}$ (または $\mathrm{Ni}$ ) を複合した材料が， $\mathrm{Pb}$ フリーはんだごてのチップ用として

*1 広島工業大学大学院生, 現在 : 井関農機 (Graduate Student, Hiroshima Institute of Technology, Present address: Iseki Corp.)

*2 現在：広島商船高等専門学校 (Present address: Hiroshima National College of Maritime Technology)

*3 広島工業大学大学院生 (Graduate Student, Hiroshima Institute of Technology)
優れた濡れ性や溶食性を有していることを明らかにし, 報告 してきた ${ }^{3,4)}$.しかし熱衝撃特性については，これまでほと んぞ調査してこなかった，また，これまでははんだの濡れ性 を主に接触角測定法 (JIS R 3256)によって評価してきた が，そのときの試験温度 (チップ材の表面温度)も $503 \pm 3 \mathrm{~K}$ $(\mathrm{Pb}$ フリーはんだの融点付近)の一種類のみしか確認してき ておらず，しかも他の細かい試験条件が濡れ角に及ぼす影響 については，ほとんど検討してこなかった.

そこで本研究では, まず両複合材 $\left(\mathrm{Fe} / \mathrm{Al}_{2} \mathrm{O}_{3}\right.$ または $\mathrm{Ni} /$ $\left.\mathrm{Al}_{2} \mathrm{O}_{3}\right)$ の熱衝撃特性に及ぼす諸因子の影響について調べ，こ の点からこれらがチップ材として十分な役割を果たすか否か を検討した. 次に, 本複合材の濡れデータの信頼性をより高 めるため, 濡れ接触角に及ぼす各試験条件の影響をいくつか 調べ，それを溶融 $\mathrm{Pb}$ フリーはんだに対するチップの濡れ性 評価基準を確立する際の基礎的資料に供する。

\section{2. 実験方法}

\section{1 供試材および試験片}

供試材は, 前報3,4) と同様, $\mathrm{Al}_{2} \mathrm{O}_{3}$ 粉末 (純度 $99.99 \%$, 平 均粒径 $0.15 \mu \mathrm{m}$ ) に $\mathrm{Fe}$ (純度 $99.5 \%$, 平均粒径 $5 \mu \mathrm{m}$ ) または $\mathrm{Ni}$ (純度 $99.9 \%$, 平均粒径 $4.30 \mu \mathrm{m}$ )をそれぞれ適量添加し たものをボールミルにより $24 \mathrm{~h}$ 湿式混合粉砕し, HP 焼結 
(ホットプレス焼結)させて作製した. $\mathrm{HP}$ 焼結は $\mathrm{N}_{2}$ 雾囲気 中, プレス圧力 $20 \mathrm{MPa}$, 焼結温度 $1573 \mathrm{~K} \times 7.2 \mathrm{ks}$ の条件 下で行った．焼結後の試料 (寸法 $10 \mathrm{~mm} \times 30 \mathrm{~mm} \times 40 \mathrm{~mm}$ 矩形状) は, 接触角測定用の試験片として, $5 \mathrm{~mm} \times 10 \mathrm{~mm}$ $\times 40 \mathrm{~mm}$ ，曲げ試験および熱衝撃試験用の試験片として，3 $\mathrm{mm} \times 4 \mathrm{~mm} \times 40 \mathrm{~mm}$ さらにウェッティングバランス試験用 の試験片として, $0.8 \mathrm{~mm} \times 10 \mathrm{~mm} \times 30 \mathrm{~mm}$ の計 3 種類に機 械加工を行い, 最終的にバフで鏡面仕上げを行っている.こ のような各試験片を, アセトン中で $3.6 \mathrm{ks}$ 間超音波脱脂洗 浄後, 温風乾燥させ, デシケータ内で保存後順次試験に供し た。な打， $\mathrm{Al}_{2} \mathrm{O}_{3}$ に複合させた粉末 $(\mathrm{Fe}$ 抢よび $\mathrm{Ni}$ 成分) の主 たる添加量は，前報）と同様 80 mass\%(以下それぞれ Fe 80 および Ni80 と略称する) としたが, 比較用として添加量が 20, 60, 70, 90, 100 mass\%のものも用意した.

\section{2 熱衝撃試験}

ごてチップは作業中常に加熱冷却という熱衝撃をうける ため, 必然的に耐熱衝撃性が要求される. そこで, 熱衝撃試 験法 (相対法：JIS R 1648)によって各試料の熱衝撃特性を 評価した。すなわち，Fig. 1 に示すように，まず試験片を大 気中昇温速度 $5 \mathrm{~K} / \mathrm{min}$ で所定温度まで加熱保持後, 直ちに 温度 $T=293 \pm 3 \mathrm{~K}$ に保持させて抢いた水槽中に投入後 ·急 冷させた.

次に，その試験片を大気中に取り出し，3 点曲げ試験 (JIS $\mathrm{R}$ 1601) を行い曲げ強度 (残存曲げ強度) $\sigma_{\mathrm{BT}}$ を調べた。熱衝 撃特性の評価は, 熱衝撃を与えた後の曲げ強度が急激に低下 し始めたときの熱衝撃温度差 $\Delta T_{\mathrm{C}}$ (試料加熱温度から冷却水 の温度を差し引いたもので, 臨界急冷温度差ともいう) 抢よ び上記残存曲げ強度 $\sigma_{\mathrm{BT}}$ で行った。

\section{3 濡れ性の評価}

本試験で作製したはんだごてチップの濡れ性評価基準の確 立を行うため, 濡れ接触角に及ぼす試験方法等の影響につい て調べた。まず，前報3,4) まで採用した接触角測定法 (JIS R 3257, 以下, CA 法と略称) についてもいくつか調べてみ た。すなわち，試験片の表面温度を $503 \pm 3 \mathrm{~K} ， 573 \pm 3 \mathrm{~K}$ お よび $623 \pm 3 \mathrm{~K}$ の 3 種類とし, そのうち最高温度の $623 \pm 3$ $\mathrm{K}$ の場合は，保持時間を $100 \mathrm{~s}, 400 \mathrm{~s}, 700 \mathrm{~s}$ および $1000 \mathrm{~s}$ の 4 通りに変化させて濡れ角を調べた。試験に用いたはんだは 市販の $\mathrm{Pb}$ フリーはんだ $(\mathrm{Sn}-3.5 \mathrm{Ag}-0.5 \mathrm{Cu})$ である.

次に, CA 法で得られた結果が他の方法で得られた結果と 対応しているか否かを調べるため, 一部の試料について全く 別のウェッティングバランス法 (JIS Z 3198, 以下 WB 法と 略称)で濡れ性を調べた。 WB 法とは, Fig. 2 に示すよう に，例えば $523 \pm 3 \mathrm{~K}$ の溶融はんだに浸漬した試験片の表面 に作用する力の変化を時間経過ごとに測定し, 濡れ力 $F$ と 濡れ時間 $t_{\mathrm{w}}$ の関係から濡れ性の評価を行うものである(濡れ 力 $F$ が大きい程濡れ易いことを意味する). なお，試験片を 溶融はんだへ浸漬させた垂直寸法 (浸漬深さ) は $2 \mathrm{~mm}$, 浸漬 速度は $2.8 \mathrm{~mm} / \mathrm{s}$ さらに浸漬時間は $10 \mathrm{~s}$ 間(一定)とした。 (a)

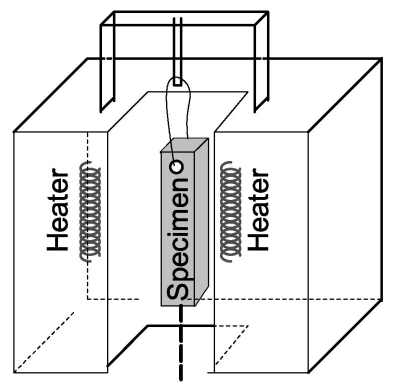

In Water

(b)

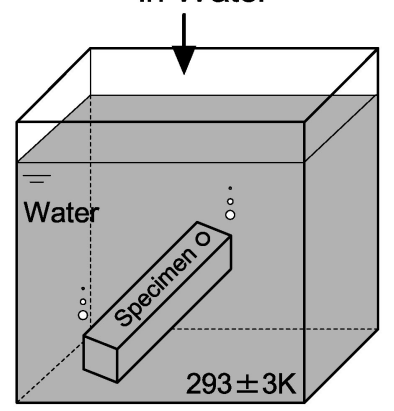

Fig. 1 Schematic illustration of thermal shock examination method.

(a) Heating (b) Water-cooled

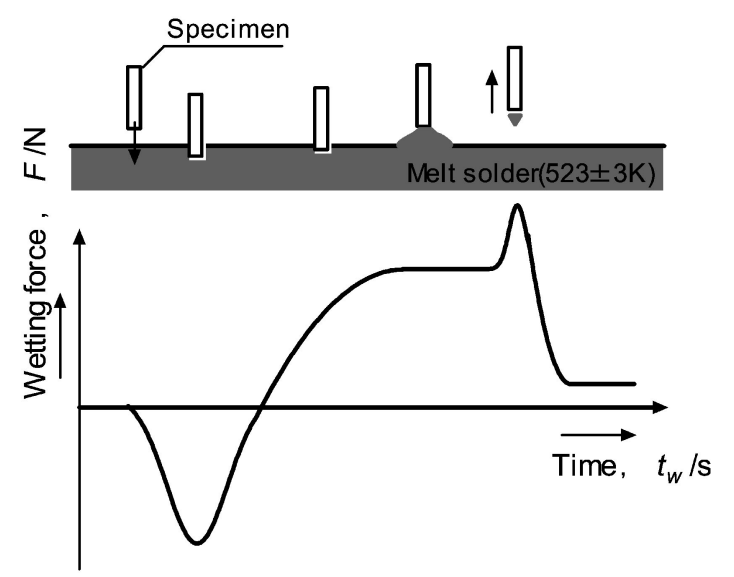

Fig. 2 Schematic illustration of wetting balance method.

\section{4 組織観察および成分分析}

破面観察，成分分析には SEM および EPMA を用いた。 後者の分析条件は加速電圧 $20 \mathrm{kV}$, ビーム電流約 $5.9 \mathrm{nA}$, ビーム径が $1 \mu \mathrm{m}$ である. 一方, 濡れ性に及ぼす大気加熱に よる試料表面の酸化の影響をXPS で調べた。分析条件は, 励起 X 線源 $\mathrm{MgK} \alpha$, 加速電圧 $15 \mathrm{kV}$, アノード電流 $10 \mathrm{~mA}$ とし，測定範囲は $1 \mathrm{~mm} \times 2 \mathrm{~mm}$ とした。な抢，できるだけ 本試料が加熱以外の酸化の影響を受けにくくするため, 加熱 後デシケータ内で自然冷却後, アセトン中で所定時間超音波 脱脂洗浄を行い直ちにXPS で分析を行った.

\section{3. 結果および考察}

\section{1 金属/セラミックス複合材の熱衝撃特性および破面形態}

2.2 で示した方法で $\mathrm{Ni} / \mathrm{Al}_{2} \mathrm{O}_{3}$ およよ゙ $\mathrm{Fe} / \mathrm{Al}_{2} \mathrm{O}_{3}$ 複合材の熱 
衝撃特性を調べた. Fig. 3 に両複合材の急冷温度差 $\Delta T$ と残 存曲げ強度 $\sigma_{\mathrm{BT}}$ の関係を示している。これより, 両材とも $\sigma_{\mathrm{BT}}$ は臨界急冷温度差 $\Delta T_{\mathrm{C}}$ (図中破線で示す) を越えると急 激に低下していることがわかる。 また，両材の $\Delta T_{\mathrm{C}}$ は Ni80 が約 $450 \mathrm{~K}, \mathrm{Fe} 80$ が約 $500 \mathrm{~K}$ と Fe80 の方がやや高くなっ ている。 一方, $\Delta T_{\mathrm{C}}$ 以上での $\sigma_{\mathrm{BT}}$ は, $\mathrm{Ni} 80$ が約 $250 \mathrm{MPa}$ であるのに対し，Fe は約 $400 \mathrm{MPa}$ とかなり高い值になって いる．このことから，熱衝撃特性は，Fe80の方が Ni80 よ り優れていると言えよう。参考までに， Ni 抢よび $\mathrm{Fe}$ の添加 量をこれらより約 1/4 (20 mass\%) に減少した複合材（これを $\mathrm{Ni} 20, \mathrm{Fe} 20$ と略称する)についても同様に調べてみた。それ をFig. 4 に示す。これより，両材とも $\Delta T_{\mathrm{C}}$ が約 $250 \mathrm{~K}$, $\sigma_{\mathrm{BT}}$ が約 $80 \mathrm{MPa}$ であり，この值は添加量の多い(80 mass\%)Fig. 3 のそれに比べるとかなり低い值であることが わかった。

そこで，Ni80 および Fe80 について，熱衝撃試験後の試 料表面抢よび破断面の SEM 観察を行った。前者の結果を Fig. 5 に，後者のそれを Fig. 6 に示す. まず Fig. 5 による と, Ni80の場合, 熱衝撃試験後 $\Delta T \approx 400 \mathrm{~K}$ 付近から黒色 の $\mathrm{Al}_{2} \mathrm{O}_{3}$ と思われる凝集体 ${ }^{3)}$ が認められ，それを起点とする き裂の生成が確認され， $\Delta T \approx 500 \mathrm{~K}$ 以上になると，き裂は さらに大きく進展している様子が認められている. 一方 $\mathrm{Fe} 80$ の場合， $\Delta T \approx 500 \mathrm{~K}$ 以上になるとき裂が表面に確認さ れたが，逆に低い $\Delta T \approx 400 \mathrm{~K}$ 付近ではそれはほとんど確認 されなかった。ところで，こうした複合材料に熱衝撃(又は 熱サイクル)が加わると，とくに冷却時に熱膨張率が小さい セラミック粒子に引張の熱応力が加わり，それを起点にき裂 が発生するとされている5)。本研究の場合，き裂は主に $\mathrm{Al}_{2} \mathrm{O}_{3}$ 凝集体を起点として発生・進展したものと思われる. 一方 Fe80 の場合， $\mathrm{Ni} 80$ のように $\mathrm{Al}_{2} \mathrm{O}_{3}$ 凝集体はほとんど 確認されておらず，しかも粒子を起点として発生したと予想 される結果も観察されていない。これらの点のより詳細につ いては今後の検討課題である. 次に熱衝撃後の破断面 (Fig. 6(a)，(b))は，Ni80(同図(a)) および Fe80(同図(b)) ともに ディンプル状の破面が観察され，延性的な破壊様相であるこ とがわかる．このように，両材間での破面様相に大きな違い は認められないものの，上述のように， $\Delta T_{\mathrm{C}}$ は Fe80の方が Ni80 より高くなっている，そこで参考のために， Ni20 およ び Fe20 両材の破面観察を行った(同図 (c) (d) 参照)。その結 果，両材とも粒界割れであり，ほとんど差がないことがわか った。本報では結果を省略しているが，Ni80，Fe80 は Ni （または $\mathrm{Fe}$ )が，また $\mathrm{Ni} 20 ， \mathrm{Fe} 20$ は $\mathrm{Al}_{2} \mathrm{O}_{3}$ がそれぞれの主 成分であることは EPMAにより確認している。したがって, Ni80，Fe80 はこうした主成分特有の延性的な破壊を，逆に $\mathrm{Ni} 20$ および $\mathrm{Fe} 20$ は $\mathrm{Al}_{2} \mathrm{O}_{3}$ 特有のぜい性的な破壊を起こし ているものと考えられる.

\section{2 熱衝撃特性に及ぼす添加成分の影響}

熱衝撃に及ぼす影響因子については，様々な角度から報告 がなされている ${ }^{1,6,7)}$ 。例えば熱伝導率が大きく，気孔率が高 いもの程一般に熱衝撃特性は向上するとされている ${ }^{6)}$. とく に，複合材の場合は，母材と複合粒子の熱膨張係数差が，熱
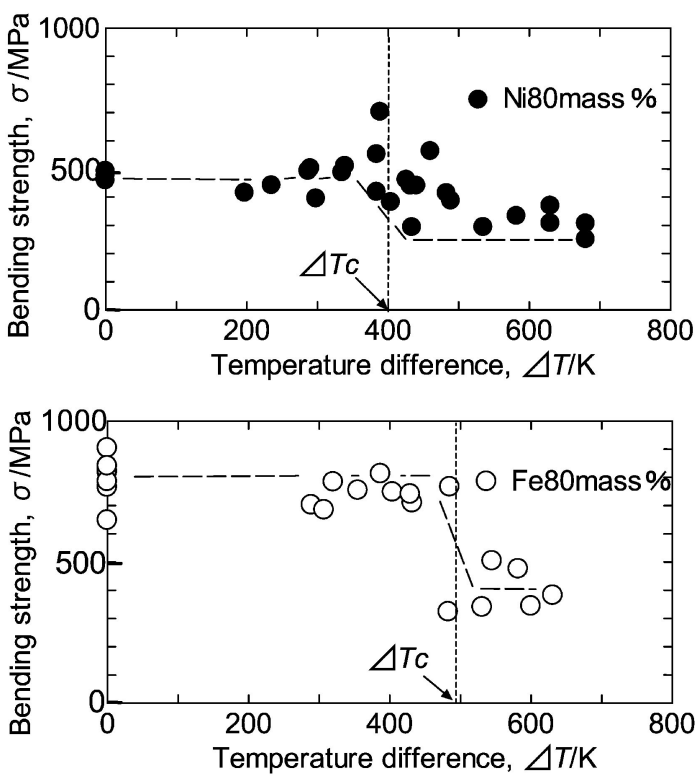

Fig. 3 Relation between bending strength $\sigma_{\mathrm{BT}}$ after thermal shocking and temperature difference $\Delta T(\mathrm{Ni} 80, \mathrm{Fe} 80)$.
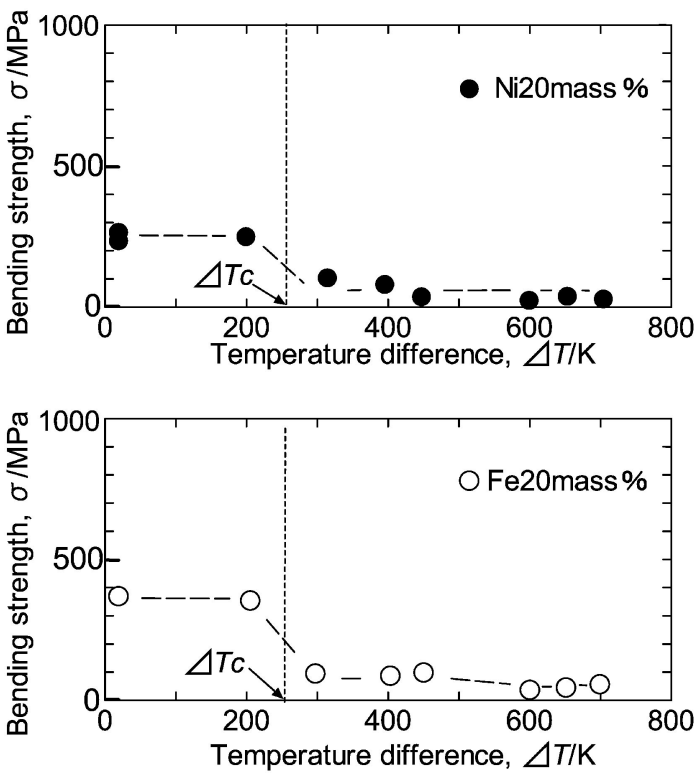

Fig. 4 Relation between bending strength $\sigma_{\mathrm{BT}}$ after thermal shocking and temperature difference $\Delta T(\mathrm{Ni20}, \mathrm{Fe} 20)$.

衝撃特性に大きく影響する. 本研究の複合材についても各因 子ごとにまとめ, 両材の比較を行ったのが Table 1 である. これによると熱伝導率は Fe80 の方が Ni80 よりもごく僅か 小さいが，気孔率は両者間でほとんどその差がない。これよ り熱衝撃特性は， $\mathrm{Fe}$ 添加材の方が若干低いか，またはあま り変わらないことが予想される。しかし，前述の結果からは Fe80の方が高くなっている. これは, Table 1, 2 に示して いるように Fe80 の方が Ni80 より破壊じん性值 $K_{\mathrm{C}}$ が高い (Ni80，Fe80 は IF 法による $K_{\mathrm{C}}$ の測定が困難であったた め，参考としてNi60 抢よび Fe60の結果を記載している)た めと考えられる。 また，若干 Fe 80 の方が熱膨張係数差が小 さかったことも関係しているものと考えられる．すなわち， $\mathrm{Fe}$ 複合材の方がじん性值は高く, 異種材料間の熱膨張係数 

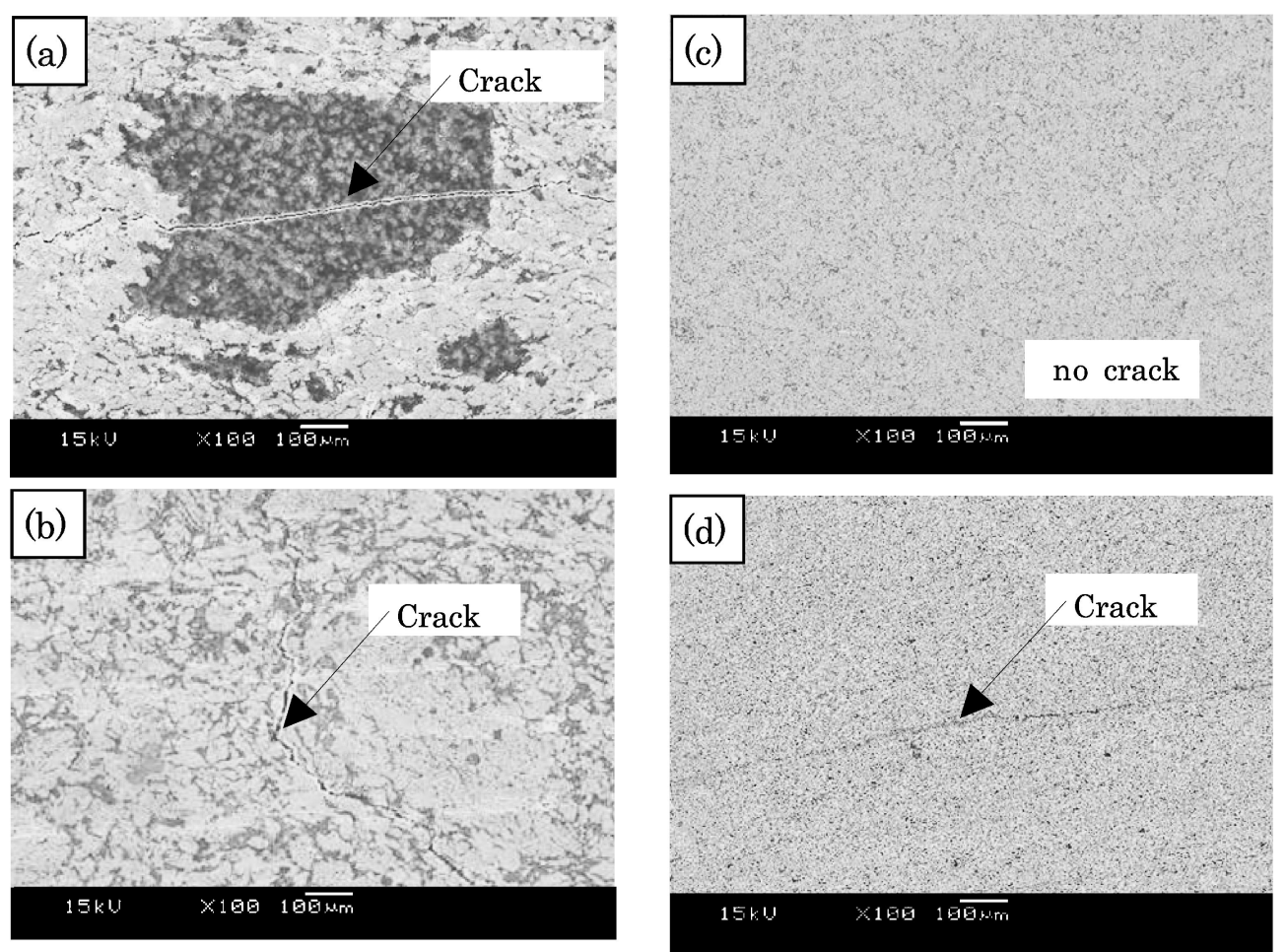

Fig. 5 SEM observation of the surface after thermal shock.

$\begin{array}{llll}\text { (a) } \operatorname{Ni} 80(\Delta T \approx 400 \mathrm{~K}) & \text { (b) } \operatorname{Ni} 80(\Delta T \approx 500 \mathrm{~K}) & \text { (c) } \mathrm{Fe} 80(\Delta T \approx 400 \mathrm{~K}) & \text { (d) } \mathrm{Fe} 80(\Delta T \approx 500 \mathrm{~K})\end{array}$
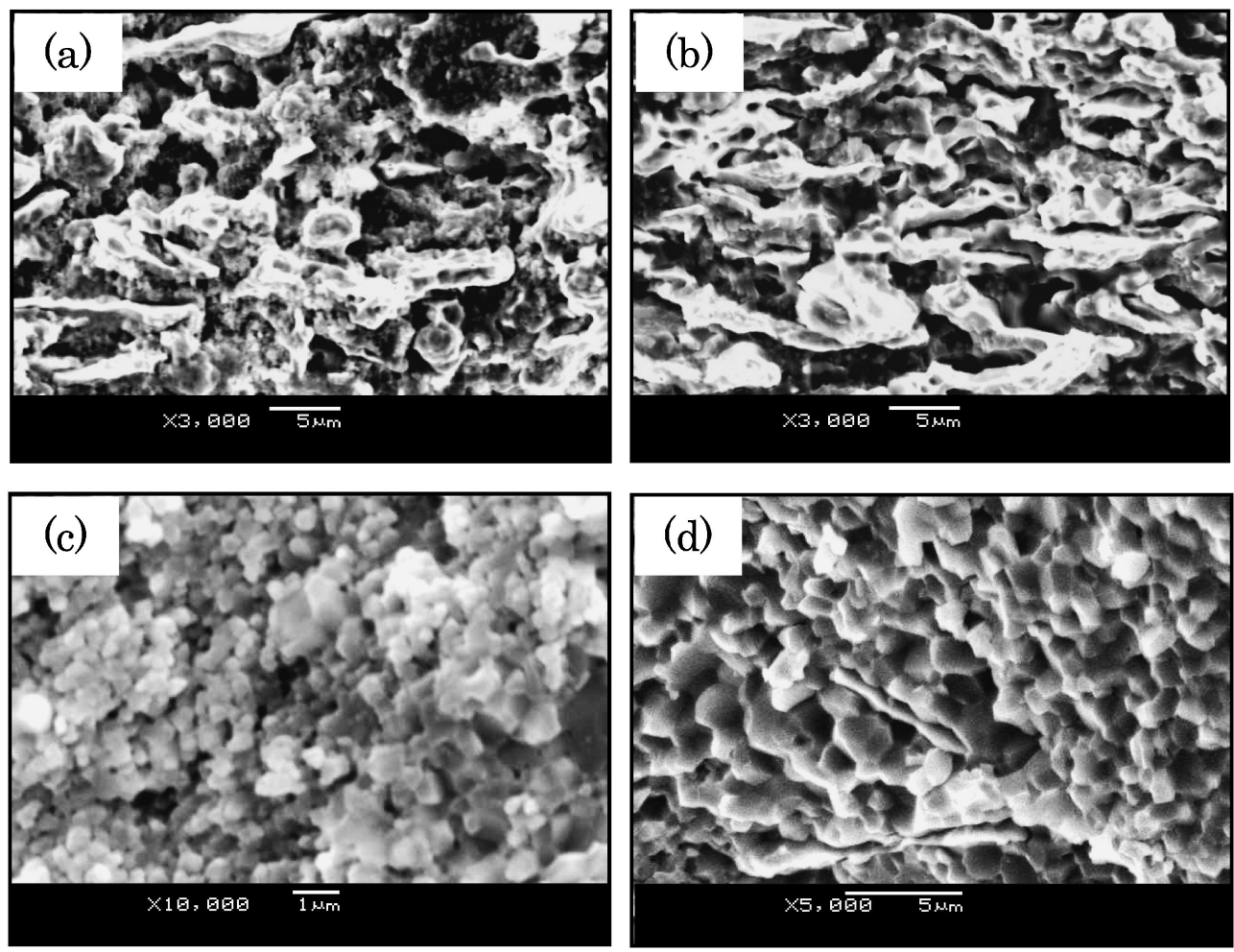

Fig. 6 SEM observation of the fracture after thermal shock.

$\begin{array}{llll}\text { (a) } \operatorname{Ni} 80(\Delta T=700 \mathrm{~K}) & \text { (b) Fe80 }(\Delta T=700 \mathrm{~K}) & \text { (c) } \operatorname{Ni} 20(\Delta T=700 \mathrm{~K}) & \text { (d) } \mathrm{Fe} 20(\Delta T=700 \mathrm{~K})\end{array}$

差によって起こる熱応力が小さいため，き裂は発生しにく く，より大きな熱衝撃を受けてもそれに耐えることができる ものと考えられる。 また，前記 Fig. 3 および 3.1 で明らか なように，もともと常温下での曲げ強度が高いことや， Fe 複合材は $\mathrm{Ni}$ 複合材のような粗大な $\mathrm{Al}_{2} \mathrm{O}_{3}$ 凝集体が存在して
いないことも原因と考えられ，これらのことが，残存曲げ強 度の向上に寄与しているものと思われる。

ところで，一般にはんだごての使用温度は $623 \mathrm{~K}(\Delta T \approx$ $350 \mathrm{~K})$ 付近であるが，Fe80，Ni80 はそれをやや上回る温度 まで強度低下が認められなかった $\left(\Delta T_{\mathrm{C}} \geqq 400 \mathrm{~K}\right)$ 。したがっ 
Table 1 Factors influence on thermal shock behavior.

\begin{tabular}{lcc}
\hline \multirow{2}{*}{ Factor } & \multicolumn{2}{c}{ Composite } \\
\cline { 2 - 3 } & Ni80 & Fe80 \\
\hline Porosity $(\%)$ & $9 \pm 2.6$ & $8 \pm 2.8$ \\
\hline Thermal conductivity $(\mathrm{W} / \mathrm{m} \cdot \mathrm{K})$ & 45.7 & 28.6 \\
\hline Thermal expansion coefficient $(/ \mathrm{K})$ & $10.8 \times 10^{-6}$ & $10.4 \times 10^{-6}$ \\
\hline Fracture toughness $\left(\mathrm{MPa} \cdot \mathrm{m}^{1 / 2}\right) *$ & $31.6(\mathrm{Ni60})$ & $47.0(\mathrm{Fe} 60)$ \\
\hline
\end{tabular}

( Indentation Fracture method $(P=98 \mathrm{~N}))$

Table 2 Thermal expansion coefficient of $\mathrm{Al}_{2} \mathrm{O}_{3}, \mathrm{Ni}$ and $\mathrm{Fe}$.

\begin{tabular}{cccc}
\hline & $\mathrm{Al}_{2} \mathrm{O}_{3}$ & $\mathrm{Ni}$ & $\mathrm{Fe}$ \\
\hline Thermal expansion coefficient $(/ \mathrm{K})$ & $6.8 \times 10^{-6}$ & $13 \times 10^{-6}$ & $12 \times 10^{-6}$
\end{tabular}

Table 3 Standard deviation of solder contact angle (Fe80).

\begin{tabular}{lcc}
\hline & $\begin{array}{c}\text { Before limited the } \\
\text { condition of fixing }\end{array}$ & $\begin{array}{c}\text { After limited the } \\
\text { condition of fixing }\end{array}$ \\
\hline Standard deviation & 8.627 & 2.590 \\
\hline
\end{tabular}

て，本複合材は， $\mathrm{Ni}$ または $\mathrm{Fe}$ の添加量～ 80 mass\%でチッ プとしての耐熱衝撃性は十分にあり，とくに Fe を添加した もの $(\mathrm{Fe} 80)$ の方が，チップとして優れた熱衝撃特性を有し ていることがわかる.

\section{3 はんだの濡れ性に及ばす各種因子の影響}

一般に溶融はんだが材料表面上で濡れ・拡張する場合，は んだの接触角は材料成分および表面形態等に大きく影響され る.とくに材料表面で生成した“酸化皮膜”は，濡れ性を左 右する大きな因子である ${ }^{8,9)}$ ，そこで本研究では， $\mathrm{Fe}$ 複合材 について, 表面の酸化挙動と濡れ性の関係を調べてみた。 ず，加熱により生成した試験片表面の酸化物(本研究ではと くに $\mathrm{Fe}_{2} \mathrm{O}_{3}$ に着目した)をXPS で調べた. エッチング時間 （分析深さに相当する）と $\mathrm{Fe}_{2} \mathrm{O}_{3}$ 量の関係を Fig. 7 に示す.

これによると, 酸化物の一つである $\mathrm{Fe}_{2} \mathrm{O}_{3}$ は, 一般に表面 から内部に進むにつれて徐々に減少しているが，その程度 は, 加熱温度 $T_{\mathrm{s}}$ が高い程緩やかになっている. すなわち, 各加熱温度 $\left(T_{\mathrm{s}}\right)$ とも試験片表面には酸化物が生成するが, その厚さは温度が高いもの程大きいことがわかる. 次に, 試 験片表面での濡れ性を各温度下で調べてみたのが Fig. 8(表 面温度 $T_{\mathrm{s}}$ と接触角 $\theta$ の関係) である。これによると, $\theta$ は表 面温度 $T_{\mathrm{s}}$ の上昇につれて大きくなり濡れ性が低下してい る.これは, Fig. 9 の写真で示しているように, 加熱によっ て表面に酸化膜層が形成され，フラックス(はんだ付け用)本 来の酸化皮膜除去効果が減少し, 濡れ性の低下をもたらした ものと考えられる.もち万ん, フラックスそのものの酸化は ある程度 $\theta$ を上昇させ, 濡れ性にはマイナスに作用してい る.ところで, 結果は省略しているが酸化の加熱時間 $t_{\mathrm{h}} に$ よる変化を調べてみた。すなわち, 加熱温度を $623 \pm 3 \mathrm{~K}$ (一 定）とし，保持時間 $t_{\mathrm{h}}$ を種々変化させたときの表面成分分析 を Fig. 7 と同様な方法で調べたところ， $t_{\mathrm{h}}$ が長い程厚い酸 化皮膜の形成が行われていることがわかった。そこで $t_{\mathrm{h}}$ と 濡机性の関係を調べたが，その結果を Fig. 10 に示す。これ

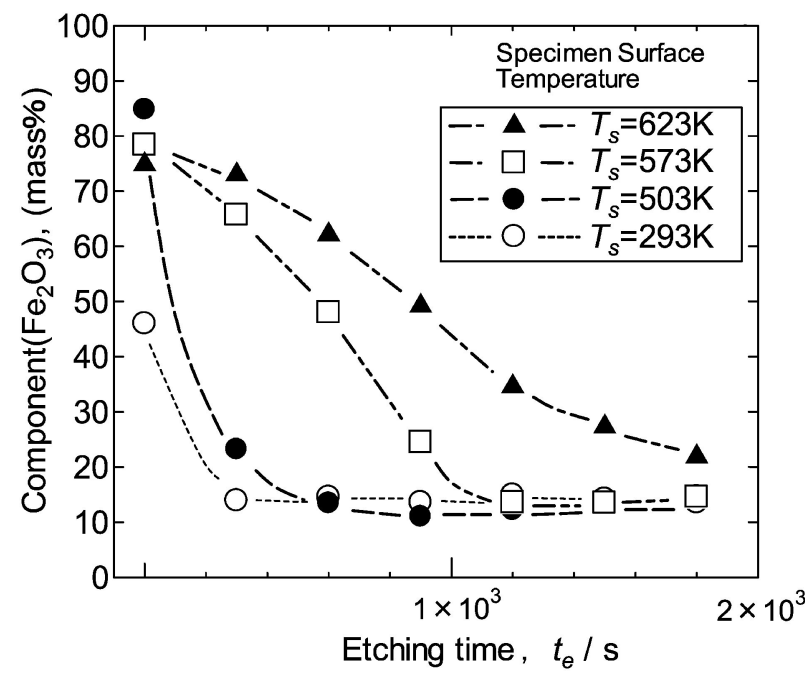

Fig. 7 Relation between the etching time and amount of $\mathrm{Fe}_{3} \mathrm{O}_{4}$ on specimen surface after heating.

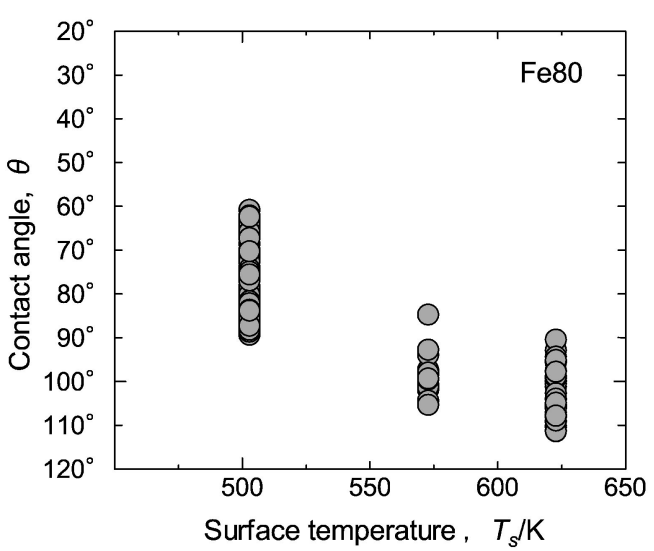

Fig. 8 Relation between solder contact angle and specimen surface temperature.

より, $t_{\mathrm{h}}$ の増加に伴い $\theta$ は上昇し濡れ性は低下していること がわかる。

\section{4 ウェッティングバランス法(WB 法)による濡れ性の評 価}

以上の結果より，はんだの濡れ性は材料表面の酸化様相に よって大きく変化するので, 濡れ性の評価に高い信頼性を持 たせるためには, 試験片の加熱温度や時間設定を厳密に規 定・管理してやる必要がある.さて, CA 法による結果の妥 当性を検討するため, 前記 2.3 および Fig. 2 で示した WB 法による濡机性評価を行った. Fig. 11 は WB 法によって求 めた $\mathrm{Fe}$ 複合材の濡孔力 $F$ と濡机時間 $t_{\mathrm{w}}$ の関係を示す。こ れより,はんだの濡れ性は $\mathrm{Fe}$ 添加量の増加に伴い向上して いることがわかる，ところで，CA 法で得られた濡れ性(需 れ接触角 $\theta)$ は, Fe 添加量の増加に伴い向上 $(\theta$ は低下)して 抢り (Fig. 12 参照), WB 法で得られた結果(図中○印; Fe 複合材の WB 法による濡れ力を示す) と十分対応しているこ とがわかる.な抢結果は省略しているが， $\mathrm{Ni}$ 複合材の場合 もこれらとほほ同様な傾向を示した。したがって,これまで 採用してきた CA 法による濡れ性評価は, 多少バラッキはあ 


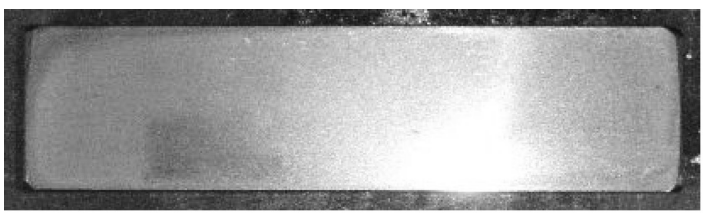

(a)

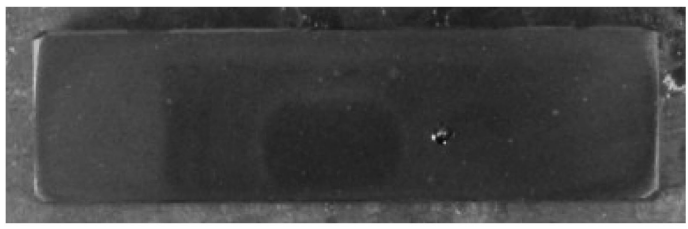

(c)

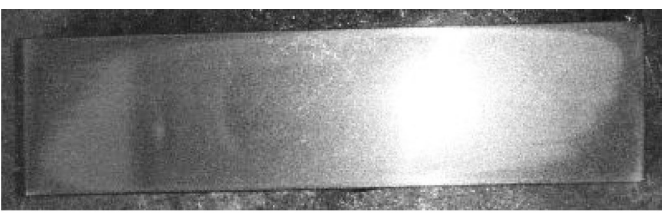

(b)

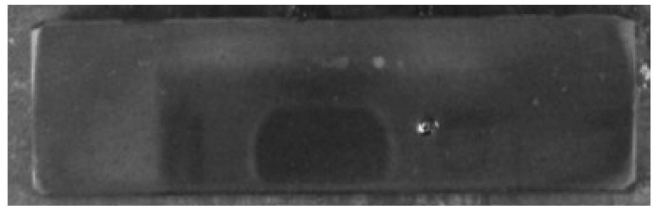

(d)

Fig. 9 Specimen surface before and after heating
(a) $\mathrm{Fe} 80\left(T_{\mathrm{s}}=293 \mathrm{~K}\right)$
(b) $\mathrm{Fe} 80\left(T_{\mathrm{s}}=503 \mathrm{~K}\right)$
(c) $\mathrm{Fe} 80\left(T_{\mathrm{s}}=573 \mathrm{~K}\right)$
(d) $\mathrm{Fe} 80\left(T_{\mathrm{s}}=623 \mathrm{~K}\right)$

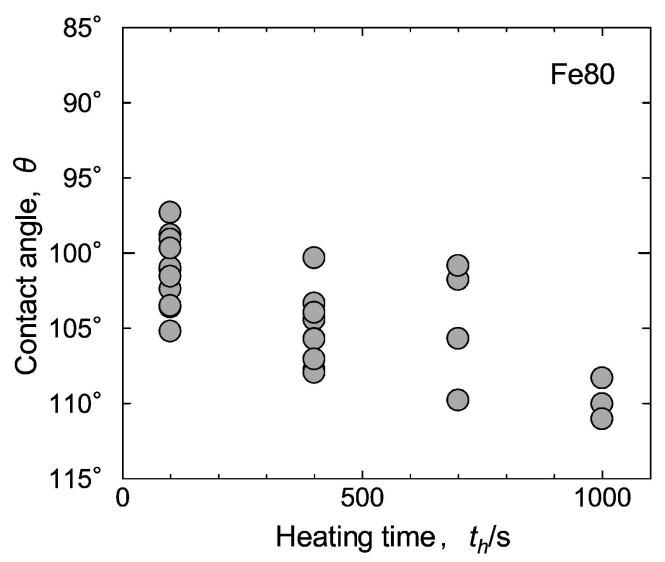

Fig. 10 Relation between solder contact angle and specimen surface temperature.

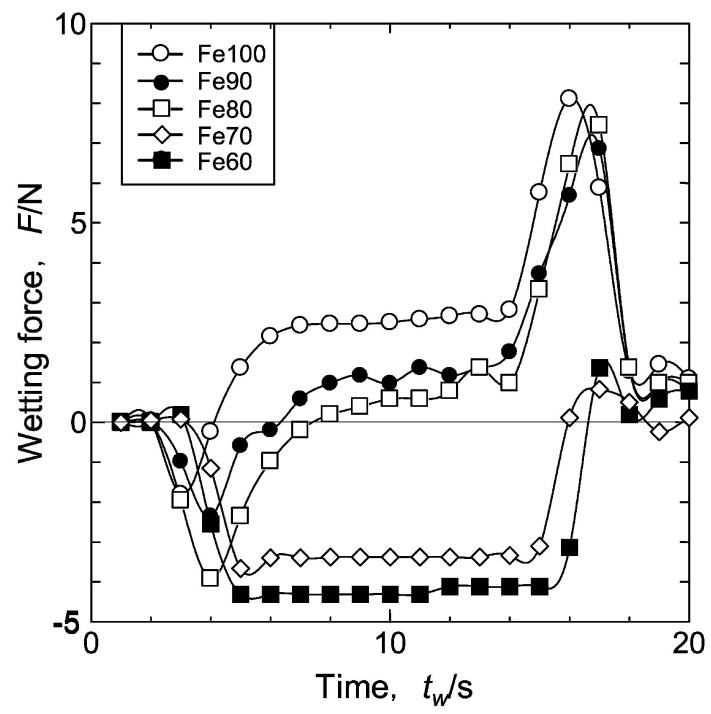

Fig. 11 Relation between wetting force and wetting time.

るものの，信頼性の高いデータであることがわかる.

一方， $\mathrm{CA}$ 法は前報3,4) と同様 $\mathrm{DM}$ (デジタルマイクロス コープ)を用いて計測・評価してきたが, 人為的なものや撮

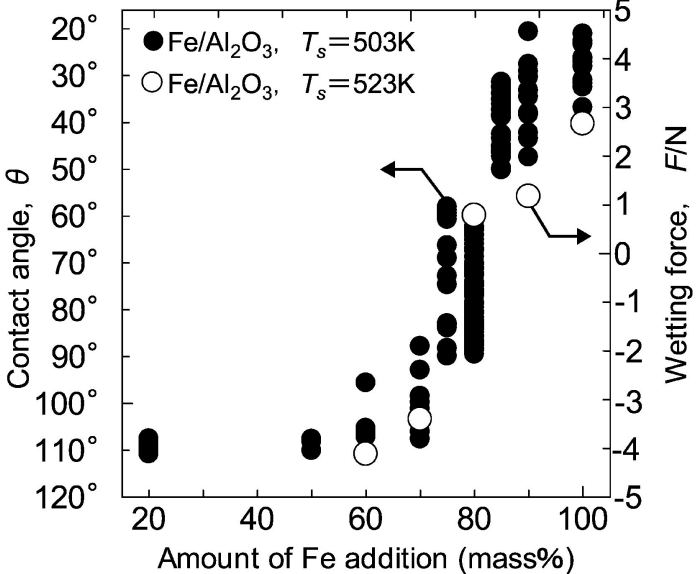

Fig. 12 Relation between solder contact angle and amount of Fe addition.

影機(カメラ)の固定条件などによっても測定值に誤差やバラ ツキを生じることがある，そこで，カメラの固定方法拉よび 位置(試験片までの距離)を限定した場合のバラツキについて 調べてみた．詳細は省略するが，カメラの固定条件を厳格に 制限した場合とそうしなかった場合の両方について，得られ た接触角の標準偏差を Table 3 にまとめて示している．これ より，固定条件を制限した場合の方が当然乍らバラツキは少 ないことがわかる。このように，CA 法も観察条件に制限を 設けてやればある程度データのバラツキを押さえることが可 能である(な拉，本結果 (Fig. 8，10，12) は観察条件を制限 する前のものである). 今後は測定 (観察) 条件の規定 (標準) 化と手法の見直し，自動化等を検討することで，データの信 頼性向上を図っていく必要がある.

\section{4. 結訇}

本研究では, まず金属/セラミックス複合材の熱衝撃特性 を調べ，それがはんだごてチップ材として十分なる耐熱衝撃 特性を有しているか否かについて検討を行った，次に，はん 
だ濡れ性の信頼性向上を図るため, 濡れに及ぼす各影響因子 について調べ，濡れ性評価基準の確立を図るべく種々検討を 行った，得られた結果は，以下の通りである.

（1）本研究で創製・開発した金属/セラミックス複合材の 同一製造 (粉末混合) 条件下での臨界熱衝撃温度差 $\Delta T_{\mathrm{C}}$ と残 存曲げ強度 $\sigma_{\mathrm{BT}}$ は，金属成分の添加量が 20,80 mass $\%$ とも に $\mathrm{Fe}$ 複合材の方が $\mathrm{Ni}$ 複合材よりも高く，熱衝撃特性に優 れていることが判明した。 これは, 添加(複合)成分による組 織の違いによるものと考えられる.

（2）本複合チップ材のはんだに対する濡れ性は，チップ表 面温度や加熱保持時間によって変化した. これはチップ加熱 条件により表面の酸化様相が異なったためと考えられる.し たがって，高い信頼性のもとで濡れ性評価を行うには，それ らの設定を厳密に制限してやる必要がある.

\section{文献}

1) G. C. Aneziris, U. Klippel, W. Schaerfl, V. Stein and Y. Yi: Int. J. Ceram. Tech. 4(2007) 481-489.

2) Z. Jin and Y. Feng: Int. J. Solids Struct. 45(2008) 5973-5986.

3) T. Tokuda, M. Kido, F. Suzumura, K. Matsubara and S. Okada: J. Japan Inst. Metals 70 (2006) 769-774.

4) T. Tokuda, F. Suzumura, K. Ohtani, K. Sato and M. Kido: J. Japan Inst. Metals 71(2007) 330-335.

5) Y. Kagawa and H. Hatta: Tailoring Ceramics Composite, (Asia Printing Office Corporation, 1990) p. 198.

6) Y. Takemoto: Journal of JWS 75 (2006) 583-588.

7) A. Kovalcikova, J. Dusza and P. Sajgalik: J. Eur. Ceram. Soc. 29 (2009) 2387-2394.

8) Y. Tiba and E. Iwamura: JETI 56 No. 12 (2008) 56-61.

9) T. Hetschel, K. J. Wolter and F. Phillipp: Circuit World 35 No. 2 (2009) 37-44. 